\title{
Workshops as a Methodological Intervention to Assess Media Literacy amongst Children with Special Reference to Learning through Cartoons in India
}

\author{
Ms. Aahana Bhatnagar Chopra \\ Ph.D Research Scholar, \\ Guru Gobind Singh Indraprastha University, New Delhi, India \\ Dr. Kulveen Trehan \\ Asst. Professor \\ Guru Gobind Singh Indraprastha University, New Delhi, India
}

\begin{abstract}
The reach of global animation industry on television in India has given kids of different age groups a choice of 350 plus animation shows (FICCI-KPMG IMEI report 2018). In India, the burgeoning mobile internet and Smartphone penetration has given rise to an alternate screen for media consumption amongst children. Therefore, it is important for children to be able to comprehend the messages in the cartoon programs. Media Literacy in children is about helping them to develop an informed and critical understanding of the nature of different media (particularly television and digital platforms). Livingstone argued that media literacy in children is the ability to access, analyze, evaluate and create messages across a variety of contexts (Aufderheide, 1993; Livingstone, 2004c, p. 18). In a mediated society, the focus is to develop children's understanding of how media functions and how it produces meanings to analyse the impact it has on little minds. Media literacy leads to critical thinking and increase awareness in everyday life (Center for Media Literacy, 2008). Therefore, it is significant to understand critically the techniques, languages and conventions used in various cartoon programs that children watch. According to the study of current trends and approaches to media literacy in Europe (2009), Media Literacy should empower children with the critical thinking and creative problem-solving skills to make them judicious consumers and producers of information. With an objective to assess the media literacy levels of cartoon programs amongst children, workshops were conducted with 500 children in the age group of 7-12 in Delhi-NCR, India. Workshops as a methodological tool for this study entails 'action towards improvement' (Lomax, 1994: p.4). Amongst 500 children respondents, 24 focus groups were made having six children in each group. The four urban, senior secondary schools were selected from the four zones of Delhi region (North, East, West, South). The language preference of children were English and Hindi. The research paper underlines how workshops are used as an intervention to identify possible areas of improvement in terms of enhanced efficacy and/or efficiency amongst children.
\end{abstract}

Keywords: Media Literacy, Cartoon Programs, Children, Workshops, Research Methods, Focus Group Discussions.

\section{Introduction}

When you talk to young children about their favourite cartoon show, their excitement is evident from their sparkling eyes. You ask them to sing their most-liked cartoon jingle and you would see them instantly jumping off their seat replicating the cartoon character. The animated moving cartoons were meant to be for entertainment purposes (Tom Sito 2013). But off late cartoons have become a powerful tool of instruction for children (Heather L. Kirkorian, Ellen A. Wartella, and Daniel R. Anderson 2008). Cartoons have the potential to teach children mannerisms and behaviour to lead a good life. Besides improvement in communication skills, cartoons can teach the little ones how to talk to their parents and elders, and they can reiterate the moral values and can become a lesson in clearly distinguishing between right and wrong (UNESCO Teacher training manual 2008).

Animated cartoon programs are looked upon as the most entertaining medium to teach children a positive conduct of day-today life (Robert Bonham, 1999: 50). Seeing the uniqueness of cartoons in their audio-visual representation of stories, various surveys prove that the impact of cartoons on children is not short lived. (Livingstone, S. 2003; Kirsh, S.J. 2006; UNESCO-Teacher training 2008; EuroMediaLiteracy 2009; Brotherson, S. 2015.) 
Depending on different socio-cultural spaces, children tend to grab instantly the cartoons they see and hear on television, mobile phones, YouTube and other mediums. (Robert Bonham 1999: 50). The psychological aspect highlights that a child's brain is more susceptible to learn through visuals and images (Saffran 2003; Tomasello, et al. 2005).

Professor Sean Brotherson (2015) argues that till the age of 12 a child would have watched about 18,000 Hours of Cartoon; validating that the cartoons as one of the main factors that sculpture the human brain, resulting in a predetermined set of way of thinking and behaviour.

\section{How cartoons influence children}

A child is being influenced at various levels because of cartoon viewing. Media effects on children as identified by researchers may broadly be categorized into cognitive, emotional and behavioural outcomes.

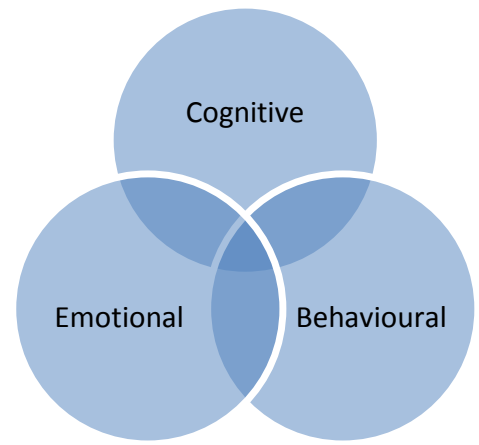

Figure No. 1- Types of influences

\section{Cognitive Influence}

Cognitive skills refers to long-term memory, sustained and selective attention, and logic and reasoning, visual and auditory processing. According to Gavriel Salomon, different media forms recruit, and develop, different cognitive processes. (Interaction of Media, Cognition, and Learning. San Francisco: Jossey-Bass, 1979). Salomon's research also provides evidence that educational programs can enhance particular cognitive abilities in children.

According to Piaget's Metatheory of Cognitive Development (1952), cognitive development was based on large-scale observational and experimental studies. He concluded that greater reasoning ability and moral development separated human beings from other animals. For Piaget, what children learn is tied to their developmental stage; it is fruitless to teach children tasks that are beyond their developmental stage. Until children attain-through natural discovery-the requisite developmental level, they are unable to understand concepts at that level (Piaget 1952). As children mature, their ability to simultaneously process greater amounts of information allows them to think more abstractly and more logically.

Adhikary (2015) in her study points out that children like acts of helping, sharing, donating, co-operating, and volunteering exhibited by their favourite cartoon character Doraemon. Doraemon stories hint deliberately and purposefully on issues that have moral and ethical connotation. This is why even the elders in the house praise this show and encourage children to prefer watching Doraemon against many other shows, hence enhancing its viewership in a big way. Her study also explores that children's interest in Doremon gadgets leads to scientific thinking, the process of acquiring knowledge by the use of reasoning, intuition, and perception.

Ajantha (2014), also talks about the positive influences of cartoons on children. The improvement of language, knowledge, cognitive skill, extra-curricular activities, talents etc. were seen among adolescents in Kanyakumari (K.K.) district.

\section{Emotional Influence}

According to Crow \& Crow (1913), an emotion "is an affective experience that accompanies generalized inner adjustment and mental and psychological stirred up states in the individual, and that shows itself in his own behaviour."(Aggarwal, 2005). The role of emotions is very vital in the personal and social development of an individual. An emotionally stable individual leads a happy, healthy and peaceful life. He is at ease with himself and his surroundings. On the other hand an individual who is emotionally disturbed becomes a problem for himself as well as for others. Continuous emotional disturbance affects the individual's growth and development. Therefore the development of emotions is extremely important for the harmonious development of the personality of an individual. (Rajawat, 2017). Some of the common emotions found in children areanger, fear, jealousy, curiosity, envy, joy, grief, affection, etc. (Hurlock, E.B. 1981). 
Deutsch (1974) and Wilson \& Cantor (1985) indicate in their researches that pre-schoolers are able to identify and differentiate basic emotions such as happiness, sadness, and fear experienced by television characters. The experimental evidence by Weiss and Wilson (1996) research involving a randomly assigned control group- demonstrates that children can transfer to real life the emotional lessons they learn from TV. Adhikary (2015), find out in her study that while watching their favourite cartoon show, children develop or experience emotional empathy with the character they like the most. Cartoon shows play a pivotal role in today's children socialization. Children at very young age identify and differentiate basic emotions. School going children easily identify emotions displayed by various characters on the show they watch that pursue them to love or hate these characters. Deepika Rajawat (2017) determined the effects of cartoons on socio-emotional development of pre-schoolers. She says that the emotional tenets seen in cartoon programmes are aggression, anger, violence, envy, jealousy, anxiety, grief, good wins over evil, joy and fun. The social tenets seen are friendship, cooperation, competition, sharing, sympathy, attachment, bravery, problem solving concept of rewards and punishment, parents as role model, imitation and many unsocial patterns too like selfishness, non-cooperation, not sharing, rivalry etc. According to her both the aspects are there the good and the bad.

\section{Behavioural Influence}

Behaviours are our actions and responses to feelings, emotions and needs. All behaviour has meaning and is closely connected to how we feel and what we think. If you are feeling happy, you may smile; if you are feeling hungry you may become irritable. Feelings themselves are neither 'right' nor 'wrong', it is how we express these feelings that is important.

When children are seen as having nice manners, are able to share with others and do as they are told, we think of them as being 'well behaved'. When children have temper tantrums, shout and stamp their feet, hit out at others or throw things, we think of them as 'bold' or 'badly behaved'. There is no such thing as a 'bad' child but there are behaviours that are not good. As with adults, a child's behaviour is an outward expression of the emotion they are feeling at the time and their behaviour, therefore, has meaning (Barnardos 2014).

Any behaviour or action the child sees may affect his personality. Television is what attracts the children most and shapes their behaviour (Kapelian 2009). Khaled Habib, Tarek Soliman (2015) concluded in their study that a cartoon program has the major portion of the children attention and time more than any activity the child performs. In modern life, where the parents are busy with their work, much less time portion of their time is given to their children, so mostly this time is passed in front of a cartoon TV series. Their study also proves that cartoons do change the children behaviour, it also changes their spoken language, as they intend to intimate the cartoons character.

Increasing Consumption of Cartoons by Indian Children in the Digital Age

As stated by FICCI-KPMG Indian Media and Entertainment Industry (IMEI) Report 2018, the use of special effects and numerous other contemporary techniques in animation is growing in India. From short animated cartoon of 10-20 minutes duration to full length feature films and web series, animated cartoons are dominating Indian Media and Entertainment Industry. The digital media consumption and animation industry are expected to grow at a compound annual growth rate (CAGR) of 25 percent and 21 percent till 2020 respectively.

Technology augmentation has brought a revolution in animation industry. Right from first CGI (computer generated imagery) to contemporary digital frames, animated cartoons have managed to bagged awards and appreciation worldwide. From VHS to DVD to Blue-ray and from black \& white TV sets to coloured HDTVs, animated cartoons have come a long way. The demand for animation has given rise to the children's content tremendously on Indian television. Disney, Viacom 18, Turner, Sun TV are the prime broadcasters of children's TV channels in India. These TV channels are catering to children from nearly all age groups starting with pre-schoolers to preteens. Every age group has something or the other on television platter. (FICCI KPMG IMEI Report 2018).

Indian broadcasters are offering plenty to children below the age of 15. (FICCI KPMG IMEI report 2017). Figure No. 2 demonstrates 
the major channels offering kids' content as per industry report.

\begin{tabular}{|lll|}
\hline \multirow{3}{*}{ Broadoaster } & Channels & Target audience age group \\
\hline & Disney & 9 to 16 \\
\cline { 2 - 3 } & Disney XD & Under 8 \\
\cline { 2 - 3 } & Disney Junior & Pre-teens and young teenagers \\
\cline { 2 - 3 } Viacom18 & Hungama & 4 to 14 \\
\hline & Sickelodeon & 8 to 17 \\
\cline { 2 - 3 } & Sonic & 10 to 17 \\
\cline { 2 - 3 } & TeenNick & Pre-teens and teenagers \\
\hline \multirow{3}{*}{ Turner } & Nick Jr & 2 to 6 \\
\cline { 2 - 3 } & Cartoon Network & 7 to 15 \\
\cline { 2 - 3 } & POG0 & 3 to 14 \\
\hline \multirow{3}{*}{ Sun TV } & Toonami & 8 to 14 \\
\hline & Chutti TV & 3 to 14 \\
\cline { 2 - 3 } & Kochu TV & 4 to 14 \\
\cline { 2 - 3 } & Chintu TV & NA \\
\cline { 2 - 3 } & Kushi TV & 3 to 14 \\
\hline
\end{tabular}

Figure No. 2: TV Channels for Children

Source: Disney annual report 2016, Network 18 annual report 2015-16, Time Warner annual report 2016, Sun Network website, FICCI-KPMG IMEI report 2017.

In India, cartoon channels have adopted a localised approach by developing domestic content. With foreign cartoons like Doraemon, Shin-Chan, Pokemon, Barbie, Ben10 etc., lots of domestic programs are coming up with shows like- Chota Bheem, Motu Patlu, Shiva, PakdamPakdai, Mighty Raju, Eena Meena Deeka, Roll No. 21, etc.

The burgeoning mobile internet and Smartphone penetration has given rise to an alternate screen for media consumption. FICCI KPMG IMEI report 2018 analysis also points out towards the OTT Video on Demand (VoD) services in the last one year. The growth of global OTT video leaders, such as 'Netflix' and 'Amazon Prime' were seen in the last one year. Platforms like 'Hotstar' and 'Sony Liv' launched premium services and dedicated channels for children. Digital platforms are flooded with children's content, where a good amount of consumption is seen on YouTube, Facebook, Voot, HOOQ etc. In the year 2018, Amazon Prime partnered with Turner India to play cartoon network's kids shows on its platform; Netflix partnered with Green Gold Animation to launch its first kids' original animated series in India called Mighty Little Bheem. Alt Balaji also entered the kids' entertainment segment with original shows. The consumption pattern also highlights the increasing focus on the localised content. YouTube is becoming the viewing platform of choice, with rising popularity particularly among the age group of 8-11 years. Within this, vloggers are an increasingly important source of content and creativity. Clearly, the trends in the IMEI report of 2018 justifies that there is higher content consumption on digital platforms by Indian children.

\section{Need for Cartoon Media Literacy}

Children need to understand media to make right choices. Media literacy is important for children for evaluating the techniques used by cartoon programs which attract their tender minds. Thinking and imagination are the factors that affect the functionality of the brain till the age of 12 . As a result, children are quite vulnerable to consume media messages incorrectly. Here, media literacy can act as an intervention, which can help children determine their future actions. (UNESCOTeacher Training Curricula for Media and Information Literacy 2008)

According to European Commission Report on Media Literacy (2009),
Media literacy should not be treated as an isolated or independent skill. On the contrary, it is a skill that involves and encompasses other skills and forms of literacy: reading and writing literacy, audio-visual literacy (often referred to as image or visual literacy) and digital or information literacy.

Thinking, conceptualising and creating media messages requires some creative skills and literacy (Skills \& Strategies for Media Education, Elizabeth Thoman 2009). The creators of media messages must know their audiences to encode media-messages in correct manner to make them understandable for the target group. Target group in this case are children. It is imperative for children to be media literate to comprehend the mass media messages and to be able to decode them properly. Media literacy leads to critical thinking and to increase awareness in everyday life. It helps children to recognize how the media filter their perceptions and beliefs, shape popular culture and influence personal choices. It empower them with the critical thinking and creative problem-solving skills to make them judicious consumers of information.

Media literacy thus includes media education, participation and active citizenship and critical 
\& creative abilities and skills. According to John Pungente,

Media Education "is concerned with helping students develop an informed and critical understanding of the nature of the mass media, the techniques used by them, and the impact of these techniques. More specifically, it is education that aims to increase students' understanding and enjoyment of how the media work, how they produce meaning, how they are organized, and how they construct reality. Media literacy also aims to provide students with the ability to create media products."

Media Literacy gives children the ability to access, analyze, evaluate and create messages across a variety of contexts (Aufderheide 1993; Livingstone 2004c, p. 18). Livingstone argued that media literacy is not only restricted to the traditional media but spawns new literacies, as diverse academic disciplines and equally diverse stakeholder interests converge on the debate, seems infelicitous, clumsy - already we have computer literacy, cyber-literacy, internet literacy, network literacy, digital literacy and information literacy, indicating convergence of media in the contemporary times.

Media literacy is potentially instrumental in proving an insight of the children's content (especially cartoon programs) in becoming a powerful tool of instruction for children. With media literacy as an intervention, the potential of cartoon programs to influence children at three levels- cognitive, emotional and behavioural, can be achieved.

\section{Review of Literature}

L.R, Huesmann (2006), while analysing the short-term and long-term effects of violent media on aggression in children and adults states that young girls who often watched shows featuring aggressive heroines in the 1970s, have grown up to be more aggressive adults involved in more confrontations, shoving matches, choking and knife fights than women who had watched few or none of these shows. Long-term content effects, in contrast, seem to be due to (a) more lasting observational learning of cognitions and behaviours and (b) activation and desensitization of emotional processes.
Rajashree S Adhikary (2015), studied the popular Japanese cartoon series Doraemon. She reveals the impact elements of Doremon from recorded statements of children. She could observe a change in their attitude and behaviour. There was an influence and imitation of characters they love. She could also see the influence on buying accessories that carry an impression of animated characters. Cognition among children who have been watching Doremon is high. Their interest in Doremon gadgets leads to scientific thinking, the process of acquiring knowledge by the use of reasoning, intuition, and perception. Doraemon stories hint deliberately and purposefully on issues that have moral and ethical connotation.

Emily S. Davidson, Amy Yasuna, and Alan Tower (1979), have found that children do notice, if any, the difference between the way female and male characters are presented in cartoons, and that is shown in the way they relate to different job preferences for males and females. As the children can depict these differences, they can easily have their vision about their future role in society distorted. This can have a great impact on the socialization process for them as children, and later as adults. Moreover, this can also interfere with their development of relationships and appropriate behavior or even their future decisions, as television can foster misconceptions of people, places or things (Davidson, Yasuna, Tower 1979).

Stevie Hossler (1978) says while talking about the mental and psychological effects of cartoons on children that 'children begin to watch and understand cartoons from the age of six months and by the age two or three children become enthusiastic viewers'. Studies show that the age group between 7 to 14 years is the most vulnerable lot to be attracted by cartoon programs on television. According to FICCI-KPMG IMEI report 2018, television continued to top media consumption among kids of 7 to 14 age group with a penetration of 97 percent. Therefore, going by general observations and other surveys (FICCI-KPMG IMEI, OFCOM, UNESCO, MILID), the target age group selected for this study is between 7 to 12 years.

OFCOM (2008) report examines children's media literacy. It provides detailed evidence on media use, attitudes and understanding 
among children and young people aged 5-15, as well as detailed information about the media access and use of young children aged 3-4.

UNESCO seminar in Seville in 2002, highlighted the need for action through active promotion policies in five areas:

1. Investigation;

2. Training;

3. Cooperation between schools, the media, NGOs, private businesses and public institutions;

4. Consolidation and promotion of the public sphere of society and its relationship with the media.

Center for Media Literacy, Beyond Blame: Challenging Violence in the Media is a 10lesson curriculum which brings together media literacy, critical thinking and conflict resolution skills to help middle school students become aware of the influences of violent media, understand the way in which violent entertainment is marketed and produced, and identify alternatives to violence in media and real life. In addition to engaging students with media clips and examples that they will readily recognize

Renne Hobbs report on Digital and Media Literacy (2010) offers a plan of action for how to bring digital and media literacy education into formal and informal settings through a community education movement. In this report, digital and media literacy are defined as a constellation of life skills that are necessary for full participation in our mediasaturated, information-rich society.

Sonia Livingstone (2003, 2007, 2009) has worked extensively on Media literacy and the challenge of new information and communication technologies. Livingstone's work on children media literacy covers all the recent debates over media literacy, elaborating the terms 'literacy' and 'media literacy', growth of media literacy from print to screen, changing literacies, Individual and institutional uses of literacy.

Thoman, Center for Media Literacy (2008) largely talks about the new ways of learning and literacy in 21st century, this talks about, why media literacy is important. The role and challenges of media are elaborately discussed which will give an edge to this research. It is a learning kit which provides a framework for learning and teaching in a Media Age. It discusses the Adapting the Questions for Different Ages and Abilities along with the strategies to be adopted to train young children about media literacy in schools, which will be very beneficial for this research.

\section{Research Question}

What is the contribution of cartoon programs in cognitive, emotional and behavioural development of children in India?

\section{Methodology}

Action Research was carried out to identify areas of concern, develop and test alternatives, and experiments with new approaches. Action research demands participation of the people in the targeted community.

For the purpose of the study, mixed methods were adopted. Various researches in determining the impact of cartoon programs on young children used the triangulation research methods. (Jaggi (2011, 2012, 2016); Wilson. T. Sebastian 2010; Vedabhyas Kundu 2014; Lynettek O. Friedrich and Aletha Huston Stein 1973; Kayla Bois \& Brad Bushman 2015).

Workshops were conducted with 500 children in the age group of 7-12 in Delhi-NCR, India. Workshops as a methodological tool for this study entails 'action towards improvement' (Lomax, 1994: p.4). Amongst 500 children respondents, 24 focus groups were made having six children in each group. The four CBSE affiliated, urban, senior secondary schools were selected from the four zones of Delhi region (North, East, West, South). The language preference of children were English and Hindi. Content analysis of the selected cartoon programs was done. The selected content was screened and discussed as a part of focus group discussions in the workshops. To assess the media literacy levels of cartoon programmes amongst children (7-12 years), focus group discussions were conducted.

\section{Themes}

This study is largely based on qualitative data analysis methods. Themes are the constructs on the basis of which the extensive workshop schedule was planned before the data collection. On the same themes, the data was eventually recorded and analysed.

Gery W. Ryan \& H. Russell Bernard (2003), points out the six techniques helpful for determining themes. These techniques are based on: (1) an analysis of words (word 
repetitions, key-indigenous terms, and keywords-in contexts); (2) a careful reading of larger blocks of texts (compare and contrast, social science queries, and searching for missing information); (3) an intentional analysis of linguistic features (metaphors, transitions, connectors); and (4) the physical manipulation of texts (unmarked texts, pawing, and cut and sort procedures). A similar model was adopted to conduct and analyse the workshops.
For conducting workshops, certain themes were identified by reviewing the literature, already-agreed-upon professional definitions, from local common-sense constructs, and from researchers' values, theoretical orientation, and personal experience with the subject matter (Bulmer 1979; Strauss 1987; Maxwell 1996). These themes (Table no. 1) were selected in order to frame questions and plan activities for the focus group discussions to understand the cognitive, emotional and behavioural influence of cartoon programs on children.

Table No. 1: Identified themes to conduct workshops

\begin{tabular}{|c|c|c|c|c|}
\hline $\begin{array}{l}\text { Theme } \\
\text { No. }\end{array}$ & Theme & $\begin{array}{l}\text { Kind of } \\
\text { Influence }\end{array}$ & Meaning/ Definition & Source \\
\hline 1. & $\begin{array}{lr}\begin{array}{l}\text { Presence } \\
\text { absence }\end{array} & \text { or } \\
\text { media } & \\
\text { literacy } & \\
\text { amongst } & \\
\text { children } & \end{array}$ & Cognitive & $\begin{array}{l}\text { To evaluate high/ } \\
\text { medium/ low media } \\
\text { literacy levels in children. }\end{array}$ & $\begin{array}{l}\text { OFCOM (2008) report } \\
\text { examines children's media } \\
\text { literacy. It provides detailed } \\
\text { evidence on media use, } \\
\text { attitudes and understanding } \\
\text { among children and young } \\
\text { people aged 5-15, as well as } \\
\text { detailed information about } \\
\text { the media access and use of } \\
\text { young children aged 3-4. }\end{array}$ \\
\hline 2. & $\begin{array}{l}\text { Recognition } \\
\text { of the source } \\
\text { of the } \\
\text { content }\end{array}$ & Cognitive & $\begin{array}{l}\text { After being exposed to } \\
\text { media, are children able } \\
\text { to answer who created } \\
\text { this content? } \\
\text { To question the two } \\
\text { fundamental insights } \\
\text { about all media - } \\
\text { 'constructedness' and } \\
\text { 'choice'. Choices are } \\
\text { made. If some words are } \\
\text { spoken; others are edited } \\
\text { out; if one picture is } \\
\text { selected, dozens may } \\
\text { have been rejected; if an } \\
\text { ending to a story is } \\
\text { written one way; other } \\
\text { endings may not have } \\
\text { been explored. However } \\
\text { as the audience, we don't } \\
\text { get to see or hear the } \\
\text { words, pictures or } \\
\text { endings that were } \\
\text { rejected. We only see, } \\
\text { hear or read what was } \\
\text { accepted! Nor does } \\
\text { anybody ever explain } \\
\text { why certain choices were } \\
\text { made. }\end{array}$ & $\begin{array}{l}\text { Centre for Media Literacy } \\
\text { (CML), } 2005 \text {. }\end{array}$ \\
\hline 3. & $\begin{array}{l}\text { Audio/ } \\
\text { Visual }\end{array}$ & Cognitive & $\begin{array}{l}\text { What techniques did } \\
\text { cartoon programs used to }\end{array}$ & $\begin{array}{l}\text { Centre for Media Literacy } \\
\text { (CML), 2005. }\end{array}$ \\
\hline
\end{tabular}




\begin{tabular}{|c|c|c|c|c|}
\hline & $\begin{array}{l}\text { formats used } \\
\text { to capture } \\
\text { children's } \\
\text { attention }\end{array}$ & & $\begin{array}{l}\text { attract the child's } \\
\text { attention? } \\
\text { This theme explores the } \\
\text { 'format' of a media } \\
\text { message and examines } \\
\text { the way a message is } \\
\text { constructed, the creative } \\
\text { components that are used } \\
\text { in putting it together - } \\
\text { words, music, colour, } \\
\text { movement, camera angle } \\
\text { and many more. }\end{array}$ & $\begin{array}{l}\text { Renne Hobbs report on } \\
\text { Digital and Media Literacy } \\
\text { (2010) offers a plan of action } \\
\text { for how to bring digital and } \\
\text { media literacy education into } \\
\text { formal and informal settings } \\
\text { through a community } \\
\text { education movement. }\end{array}$ \\
\hline 4. & $\begin{array}{l}\text { Gender } \\
\text { differences in } \\
\text { cartoon } \\
\text { consumption }\end{array}$ & Emotional & $\begin{array}{l}\text { How different children } \\
\text { understand the content } \\
\text { differently? } \\
\text { Parents and children do } \\
\text { not "see" the same TV } \\
\text { show! Each audience } \\
\text { member brings to each } \\
\text { media encounter a unique } \\
\text { set of life experiences } \\
\text { (age, gender, education, } \\
\text { cultural upbringing, etc.) } \\
\text { which, when applied to } \\
\text { the text - or combined } \\
\text { with the media message- } \\
\text { create } \\
\text { interpretations. unique } \\
\text { This theme explores how } \\
\text { gendered choices are made } \\
\text { in selecting and } \\
\text { consuming a specific } \\
\text { cartoon program. }\end{array}$ & $\begin{array}{l}\text { Centre for Media Literacy } \\
\text { (CML), 2005. } \\
\text { Deconstructing Gender in } \\
\text { Cartoon Programming on } \\
\text { Children's Television } \\
\text { Channels in India-A Textual } \\
\text { Analysis by Dr. Ruchi Jaggi } \\
(2011,2012,2016)\end{array}$ \\
\hline 5. & $\begin{array}{l}\text { Age } \\
\text { differences in } \\
\text { cartoon } \\
\text { consumption }\end{array}$ & Cognitive & $\begin{array}{l}\text { This theme comparatively } \\
\text { analyses how cartoon } \\
\text { programs influence } \\
\text { children of different ages } \\
\text { in the bracket of } 7-14 \\
\text { years. }\end{array}$ & $\begin{array}{l}\text { How do cartoons teach } \\
\text { children? A comparative } \\
\text { analysis on pre-schoolers } \\
\text { and schoolchildren by Sonia } \\
\text { Schiau, } 2013\end{array}$ \\
\hline 6. & $\begin{array}{l}\text { Values } \\
\text { depicted in } \\
\text { cartoon } \\
\text { programs }\end{array}$ & $\begin{array}{l}\text { Behavioural/ } \\
\text { Emotional }\end{array}$ & $\begin{array}{l}\text { All media carry subtle } \\
\text { messages about who and } \\
\text { what is important. It's not } \\
\text { that ideas and values are } \\
\text { embedded in media } \\
\text { messages but that the } \\
\text { values of mainstream } \\
\text { media typically reinforce, } \\
\text { and therefore, affirm, the } \\
\text { existing social system. }\end{array}$ & $\begin{array}{l}\text { Centre for Media Literacy } \\
\text { (CML), } 2005 .\end{array}$ \\
\hline 7. & $\begin{array}{l}\text { Lifestyles } \\
\text { depicted in } \\
\text { cartoon } \\
\text { programs }\end{array}$ & Behavioural & $\begin{array}{l}\text { The decision about a } \\
\text { character's age, gender or } \\
\text { race mixed in with the } \\
\text { lifestyles, attitudes and } \\
\text { behaviours that are } \\
\text { portrayed, the selection of }\end{array}$ & $\begin{array}{l}\text { Centre for Media Literacy } \\
(\mathrm{CML}), 2005 .\end{array}$ \\
\hline
\end{tabular}




\begin{tabular}{|c|c|c|c|c|}
\hline & & & $\begin{array}{l}\text { a setting (urban? rural? } \\
\text { affluent? poor?), and the } \\
\text { actions and re-actions in } \\
\text { the plot are just some of } \\
\text { the ways that values } \\
\text { become "embedded" in a } \\
\text { cartoon program. }\end{array}$ & \\
\hline 8. & $\begin{array}{l}\text { Function/ } \\
\text { purpose of } \\
\text { the cartoon } \\
\text { program }\end{array}$ & $\begin{array}{l}\text { Cognitive/ } \\
\text { Behavioural/ } \\
\text { Emotional }\end{array}$ & $\begin{array}{l}\text { Why was this content } \\
\text { created? }\end{array}$ & $\begin{array}{l}\text { Albert Bandura describes } \\
\text { social cognitive theory as the } \\
\text { reciprocal action between } \\
\text { environment, behavior, and } \\
\text { cognition, so does media } \\
\text { psychology evaluate the } \\
\text { interactive process of the } \\
\text { system. Cognitive } \\
\text { development among } \\
\text { children involves the } \\
\text { progressive building of } \\
\text { learning skills, such as } \\
\text { attention, retention and } \\
\text { processing of information. } \\
\text { These crucial skills enable } \\
\text { children to process the } \\
\text { sensory information they } \\
\text { experience and eventually } \\
\text { learn to evaluate, analyze, } \\
\text { remember, } \\
\text { comparisons and understand } \\
\text { cause and effect. }\end{array}$ \\
\hline 9. & $\begin{array}{l}\text { Ability to } \\
\text { recognise the } \\
\text { affect based } \\
\text { binaries }\end{array}$ & $\begin{array}{l}\text { Cognitive/ } \\
\text { Emotional }\end{array}$ & $\begin{array}{l}\text { The theme is selected to } \\
\text { evaluate children's } \\
\text { decision and capabilities to } \\
\text { identify the friendly and } \\
\text { violent images in cartoon } \\
\text { programs they watch. }\end{array}$ & $\begin{array}{l}\text { Stevie Hossler (1978), while } \\
\text { talking about the mental and } \\
\text { psychological effects of } \\
\text { cartoons on children. }\end{array}$ \\
\hline 10. & $\begin{array}{l}\text { Cartoon } \\
\text { programs as } \\
\text { tool of media } \\
\text { literacy }\end{array}$ & Cognitive & $\begin{array}{l}\text { Thinking and imagination } \\
\text { are the factors that affect } \\
\text { the functionality of the } \\
\text { brain till the age of } 12 \text {. } \\
\text { Therefore, children are } \\
\text { quite vulnerable to } \\
\text { consume media messages } \\
\text { absurdly. Here, media } \\
\text { literacy can act as an } \\
\text { intervention, which can } \\
\text { help children determine } \\
\text { their future actions. }\end{array}$ & $\begin{array}{l}\text { Media Literacy and New } \\
\text { Humanism, UNESCO } 2010 . \\
\text { Sonia Livingstone (2003, } \\
\text { 2007, 2009) has worked } \\
\text { extensively on Media literacy } \\
\text { and the challenge of new } \\
\text { information and } \\
\text { communication technologies. } \\
\text { Livingstone's work on } \\
\text { children media literacy } \\
\text { covers all the recent debates } \\
\text { over media literacy, } \\
\text { elaborating the terms } \\
\text { 'literacy' and 'media literacy', } \\
\text { growth of media literacy } \\
\text { from print to screen, } \\
\text { changing literacies, } \\
\text { Individual and institutional } \\
\text { uses of literacy. }\end{array}$ \\
\hline
\end{tabular}




\section{Conducting the Workshops}

The workshops were divided in four sessions (Table No. 2) - Focus Group Discussion, Recognition Based Activity, Learning by Doing Activity and Recall Based Activity. Keeping children in mind and how much attention they can give; each workshop was designed for 1 hour 15 minutes in duration. Amongst 500 children respondents, 24 groups were made having six children in each group. The four urban, senior secondary schools were selected from the four zones of Delhi region (North, East, West, South).

\section{Summary of the Workshops}

Workshops were selected as a methodological intervention to assess media literacy amongst practice of actual methods. (Centre for Community Health and Development at the University of Kansas 2018)

The focus group discussions were about general media consumption habits of children from 7 to 12 years. Questions reflected on their daily routine, their interests, their knowledge about media, their interests in cartoons, their likes and dislikes about various cartoon shows and characters, and so on.

In the recognition based activity, visual clips of some popular cartoon shows were played. This was intended towards interpretation of moving images and to recognise 'good' content (morally correct, ethical, valuable) and

Table No. 2: Workshop Design

\begin{tabular}{|c|c|c|c|c|}
\hline $\begin{array}{l}\text { Activity } \\
\text { No. }\end{array}$ & Theme & About the Activities & Methodology & Duration \\
\hline \multirow[t]{5}{*}{1.} & $\begin{array}{l}\text { Presence or absence of } \\
\text { media literacy amongst } \\
\text { children }\end{array}$ & \multirow[t]{5}{*}{$\begin{array}{l}\text { Interactive session on Media Habits } \\
\text { (About popular cartoons, use of } \\
\text { other media, likes and dislikes). }\end{array}$} & \multirow[t]{5}{*}{$\begin{array}{l}\text { Focus Group } \\
\text { Discussion }\end{array}$} & \multirow[t]{5}{*}{$\begin{array}{c}30 \\
\text { Minutes }\end{array}$} \\
\hline & $\begin{array}{l}\text { Recognition of the } \\
\text { source of the content }\end{array}$ & & & \\
\hline & $\begin{array}{l}\text { Audio/ Visual formats } \\
\text { used to capture } \\
\text { children's attention }\end{array}$ & & & \\
\hline & $\begin{array}{l}\text { Gender differences in } \\
\text { cartoon consumption }\end{array}$ & & & \\
\hline & $\begin{array}{l}\text { Age differences in } \\
\text { cartoon consumption }\end{array}$ & & & \\
\hline 2. & $\begin{array}{l}\text { Ability to recognise the } \\
\text { affect based binaries }\end{array}$ & $\begin{array}{l}\text { Playing of Visual clips: } \\
\text { Interpretation of Images (To learn } \\
\text { through moving images) } \\
\text { - Good Clips } \\
\text { - Bad Clips (Violent) }\end{array}$ & $\begin{array}{l}\text { Recognition } \\
\text { Based } \\
\text { Activity }\end{array}$ & $\begin{array}{c}20 \\
\text { Minutes }\end{array}$ \\
\hline 3. & $\begin{array}{l}\text { Values depicted in } \\
\text { cartoon programs }\end{array}$ & $\begin{array}{l}\text { Children were provided posters/ } \\
\text { placards etc. of different cartoon }\end{array}$ & $\begin{array}{l}\text { Learning by } \\
\text { Doing }\end{array}$ & $\begin{array}{c}10 \\
\text { Minutes }\end{array}$ \\
\hline & $\begin{array}{l}\text { Lifestyles depicted in } \\
\text { cartoon programs }\end{array}$ & $\begin{array}{l}\text { characters or a visual from a cartoon } \\
\text { program and they used their }\end{array}$ & & \\
\hline & $\begin{array}{l}\text { Function/ purpose of the } \\
\text { cartoon program }\end{array}$ & $\begin{array}{l}\text { imagination to create a story around } \\
\text { that visual. }\end{array}$ & & \\
\hline 4. & $\begin{array}{l}\text { Cartoon programs as } \\
\text { tool of media literacy }\end{array}$ & $\begin{array}{l}\text { Creative Storytelling: Children } \\
\text { narrated stories they created with } \\
\text { the help of visual cues. }\end{array}$ & $\begin{array}{l}\text { Recall Based } \\
\text { Activity }\end{array}$ & $\begin{array}{c}15 \\
\text { minutes }\end{array}$ \\
\hline
\end{tabular}

children with special reference to learning through cartoons in India. This is based on the theory that workshop provides a way to create an intensive educational experience in a short amount of time, when the time for a more comprehensive effort may not be available. A workshop introduce a new concept, spurring participants to investigate it further on their own, or can demonstrate and encourage the 'bad' content (unethical, immoral, abusive, violent). The screened clips were selected after one week's of semiotic analysis of some popular cartoon programs having maximum viewership. The clips were taken from: Chota Bheem, Doraemon, Pokemon, Ben10, Barbie and Shin Chan. This session was studied with respect to the Saussure's concept of interpretation of signs and symbols; signifiers 
and signified (characters, colours, settings, shots, images, visuals, dialogues, stories etc.).

In learning by doing activity children were divided in groups, having six members in each group. They picked up any poster or of a cartoon character or a visual from a cartoon program and were asked to use their imagination to create a short story in 10 minutes (in any language of their choice).

In recall based activity, the groups narrated stories they created with the help of visuals, while the children in audience gave their feedback and comments. (Figure No. 3). emotional and behavioural influences on young minds can be achieved.

The interaction with children about general media consumption habits of children discovered:

- Children (7 to 12 years) watch television for 1-3 hours every day.

- Children were excited and full of enthusiasm to talk about cartoons.

- Many of them knew how to use mobile phones and could access YouTube, Amazon Prime and other digital platforms

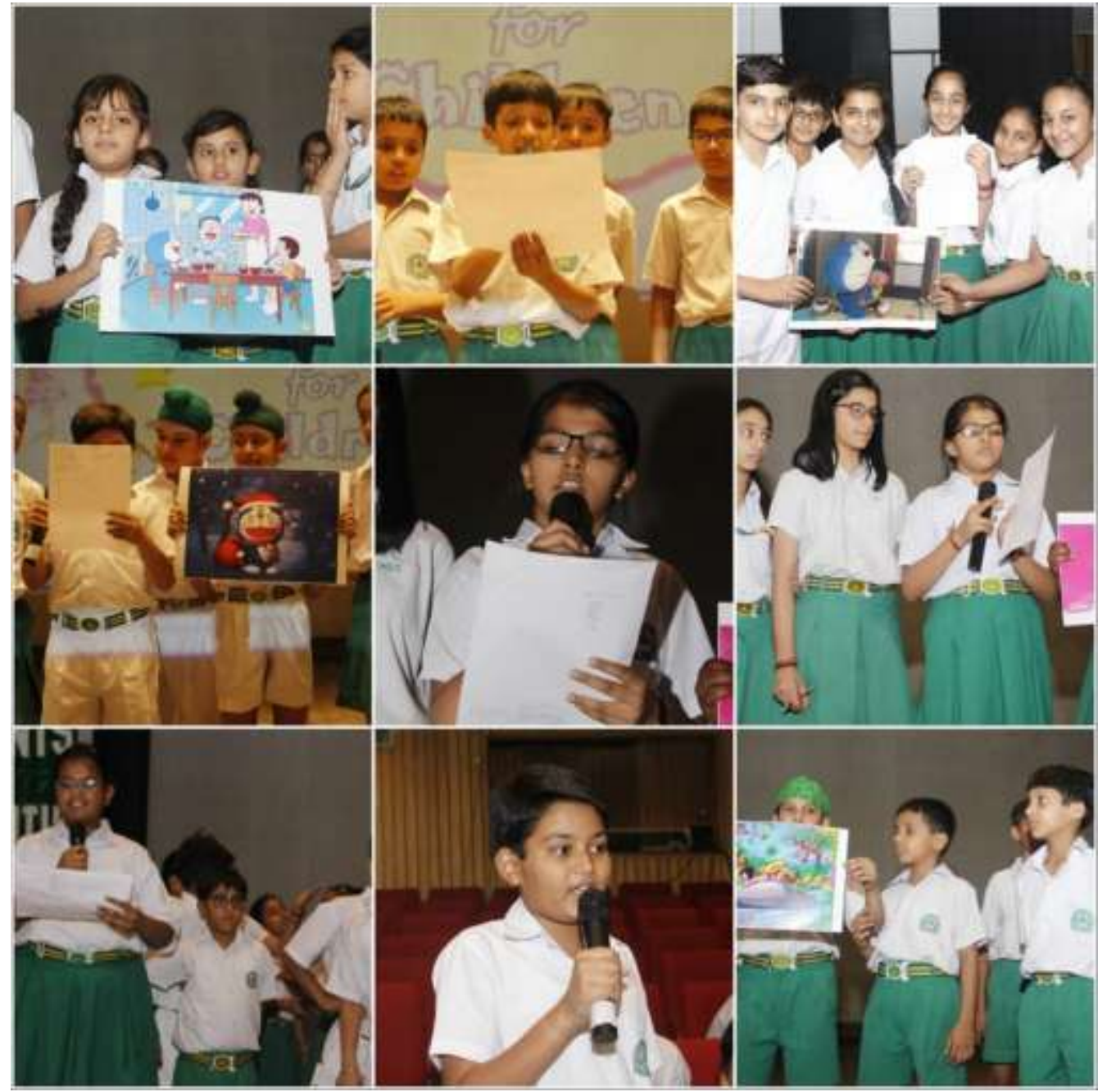

Figure No. 3: Narration of Stories by Children

\section{FINDINGS}

Media literacy is very instrumental in proving as an insight of the children's content (especially cartoon programs). It is a powerful tool of instruction for children. With media literacy as an intervention, the potential of cartoon programs to identify the cognitive, to watch cartoon programs.

- Children remembered the visuals, dialogues, one-liners and jingles from their most watched cartoon program.

- Children remembered the theme songs of cartoon shows and could sing these songs in chorus. 
- Children jumped from their seats to answer about their favourite cartoon show/ character.

- Children wish to spend half of their time in watching cartoons on television, YouTube etc.

- Their body language, expressions, gestures etc. stated their love and fascination for cartoons. at very young age were able to figure out marked differences between violent and friendly images. During the workshop, there were instances when children chose to become like Doraemon, Chota Bheem, Ben10, Mowgli etc. They find them heroic, helpful, caring, lovable. They were also able to identify 'bad' characters who were impolite with their parents, were violent, lazy and harmful. An interesting observation was pointed out in workshop no. 4 , when a respondent felt that

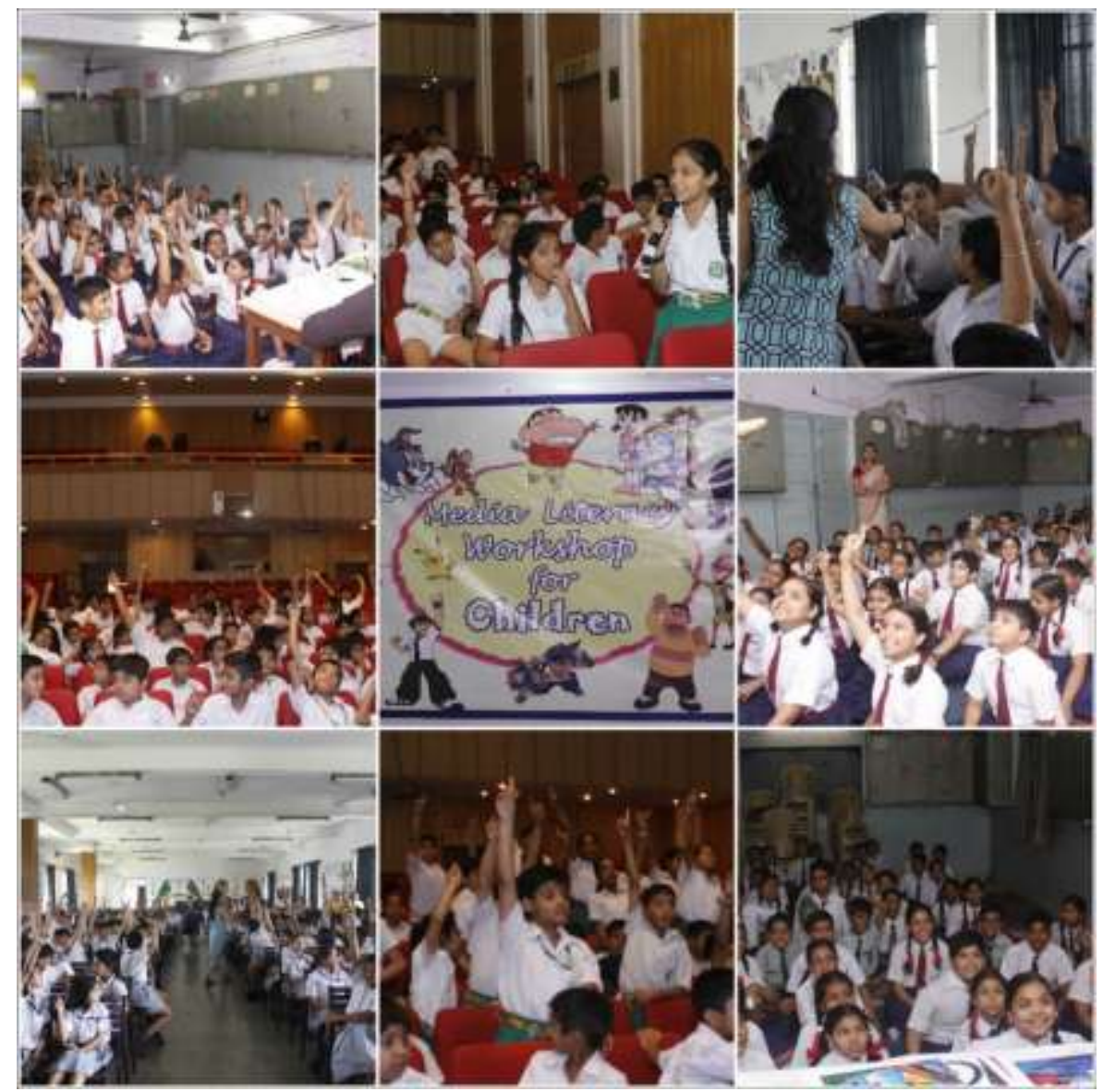

Figure No. 4: Interaction with Children about Media Habits (Workshops 1-4)

\section{Cognitive Influence}

The study suggests that media literacy can become an important building block to understand cartoon programs because it enhances children's ability to identify, read and interpret multiple media messages simultaneously.

There is a presence of media literacy observed in the respondents to some extent. It was observed that children know what is right and what is wrong in the absence of moderators and teachers. Their answers or behaviour might change in the presence of their parents, or when at home, in their own comfort zones. While the workshops concluded that children one of his classmate looks like 'Gian', an ugly looking character in the show 'Doraemon', who always fights and is bossy.

Excerpt: "He looks like Gian and acts like Gian, he fights with me all the time and complain about me every time to teacher. I don't like him." (A respondent from FGD 2, Workshop no. 4)

When questioned about do they have any knowledge of 'who created these cartoon programs?', children had a little idea about media business, media producers, media houses. Only thing they knew was programmes being accessed from different 
platforms like YouTube Kids, VOOT Kids, Amazon Prime and television channels. Some children believed that these cartoon characters exists in real. One of the respondent (Age 7, FGD 4, Workshop 1) said, 'Once I saw Ben10, he smiled at me, he was wearing an exciting cap, I asked my mom to gift me the same cap on my birthday.' On asking whether Ben10 is real or fictional, he said, 'He is of course real, he lives quite far and have friends everywhere is the world.' So the idea behind 'media constructs' are not known to children. Children from higher classes (class 6-7-8), still know that these programs are created and the characters are fictional and only exist in dreams. One of the child from FGD 18, Workshop 3 laughed when asked about the existence of these characters. He said, 'It's fascinating to possess the Ben10 watch, the Doraemon Memory Bread, Take-copter etc., but these don't exist. They are only to be seen on television for our entertainment purposes.' Children make their own choices of the content they want to watch. They have so much being offered on various platforms. But of course as pointed out by Centre of Media Literacy (2005), there is no explanation to why certain choices were made to watch a specific cartoon program.

Children also have no idea about creative components of the programmes- words, music, colour, movement, camera angle etc. Of course these have been used with an intention, there is semiotics involved in the construction of the script and screenplay. There is no cognition seen of the audio/ visual formats and elements used which could capture children's attention. Here, there is a need of the intervention to develop media literacy in children of different age groups.

Cartoon Programmes influence children of different ages differently. The consumption patterns also differ with growing age. Kayla Bois \& Brad Bushman points out that 11 years old children watch cartoon $28 \mathrm{hrs}$. Weekly. They stated that $53 \%$ of $7-12$ years old has no parental monitoring for what being watched on TV. Another research performed by researcher Sharmin, BRAC University (2015), concluded most parents prefer to leave their children in front of TV in order to finish their Work or to have a rest. Putting a child in front of the TV is the best way for a parent to make their child eat their food.
Following the studies of Kayla Bois \& Brad Bushman and Sharmin (2015), the respondents were asked about their consumption habits. Around $70 \%$ of the respondents have an easy access to television, mobile phones, I-pads and tablets. Some children even own the personal mobile phones or tablets. A child said 'My parents gifted me my own mobile phone on my $12^{\text {th }}$ birthday', on questioning about his choice of content he watches on mobile phones, he says, 'I use my mobile phone to play games, watch YouTube unboxing videos and watch Pakdam Pakdai, Ben10, Doraemon and others on Voot Kids app'. (Age 12, FGD 9, Workshop 2).

Children learn from cartoon programs. They learn the basic soft skills, cultural and moral ideas. Some Indian cartoon programs like Motu-Patlu, Roll No. 21 and Chota Bheem reiterate the moral lessons. These programs also have special episodes on festivals like Holi, Diwali, and Christmas etc. The purpose of these special episodes is to instil the progressive building of learning skills and processing of information they experience. (Social cognitive theory, Albert Bandura 1977).

The voice characteristics of each personality are distinctly different individual trademarks, and children were able to tell about different characters merely by listening to conversations. It was observed that children were fluently singing Doraemon's popular song, "Main hoon Gian...Main bada surila hoon" (FGD 1-24, Workshop 1, 2, 3, 4). The song indeed is popular but children found to be hating Gian's character. They see him as an aggressive, bully, greedy, loud and a 'bad' character.

\section{Emotional Influence}

Emotions form the basis for a child's connection to his/ her environment. Children immerse themselves in the stories, feel with or for the characters, imagine themselves in scenes, and experience the atmosphere of the situation intensively. In this aspect children experience feelings, much more strongly than adults.

The fantasies are created but children are learning from these fantasies. It is to be noted that similar opinions have also been seen in other researches. "Children derive psychological benefits from cartoon programs because the fantasy contained within them 
gratifies certain inherent needs peculiar to childhood. This is because it is during childhood that the energy and impulsiveness which form the basis of the child's personality are socialized to conform to the ideals of society." (Rajashree S Adhikary 2015). Children's fascination with 'Dokodemo Door', which can take them to their dream destination and 'Memory Bread', which help them to memorise data from school books, clearly indicated their love for fantasy. They dream of owning a 'house' like Barbie and a 'watch' like Ben10. (Workshops 1-4, FGD 1-24).

Girl respondents were mostly interested to watch Barbie, while Ben10 and Pokémon were more liked by the boys. On asking one of the girl respondent (FGD 12, workshop 2), why she do not like watching Ben10, she replied 'The characters there fight a lot'. A boy from the same workshop replied, 'there is no excitement in the shows like Barbie, they are boring to watch'.

Dafna Lemish (2010) argues findings from numerous studies on portrayal of gender on various media including films, television and video games. She succinctly sums up that 'boys are identified with 'doing' in the 'public sphere', while girls are associated with 'being' in the 'private sphere'. This argument is multilayered. It highlights that the discourse on gender portrayals is such that one finds masculine representations to have higher social status in comparison with feminine representations in the media. Goffman (1976) and MacDonald (1995) argue that the constructions of femininity and masculinity are part of a dominant ideology that prescribes proper behaviour for men and women. With reference to this, the study also highlights the gender differences in cartoon consumption. Girls were largely observed owning Barbie houses, Kitchen sets, musical instruments, colour boxes and other stationery items of Alice, Cinderella, Barbie, Shizuka (Doraemon) etc. Boys found to be possessing guns, watches, cars, motor bikes, cricket kits, footballs and stationery items of Ben10, Chota Bheem, Nobita, Doraemon, Gwen Tennyson etc.

The content of cartoon programs do carry subtle messages about who and what is important. It's not that ideas and values are embedded in media messages but that the values of mainstream media typically reinforce, and therefore, affirm, the existing social system (Centre for Media Literacy, 2005). In an $A / V$ clip, screened during the workshop, Chota Bheem is seen fighting with Daku Mangal Singh and save villagers from all atrocities. Children pointed out Mangal Singh as evil, villainous, destructive, harmful and ugly. At the same time they see Chota Bheem as friendly, helpful, benevolent, kind and heroic. Some of the other stories they developed as a part of workshops are given below. The stories are taken from the copy of hand written stories written by children as a part of the workshop. (Figure No. 5)

"It was a beautiful and fresh morning. Barbie and her brother were helping their parents to clean the house. They have a big family which lives together happily. They do not fight with each other. They have unity. They help each other in their sorrow moments. They have love and affection for each other."

"आज भीम के घर मेहमान आये हैं। भीम ने दरवाज़ा खोला और नमस्कार किया । आदर सहित अन्दर घर में लाया। उसके घर पर उसके माता-पिता नहीं थे। भीम ने अपने चाचा-चाची को पानी पिलाया और पूछा कि आप कैसे हैं ? और उनसे हसी खुशी बातें करने लगा। कुछ देर बाद उसके माता-पिता घर आये तोह उन्हें बड़ी प्रसत्ता हुई कि भीम अकेला होते हुए भी मेहमानों के चेहरे पर मुस्कान लाता है ।"

"Once upon a time there was a beautiful forest. In the forest, there was a river. In the river, Mowgli was relaxing with his animal friends- Balu, Bagheera and Monkey. They all were enjoying very much. Then suddenly, monkey fell into the river and asked for help. Then Mowgli saved his life."

"One evening, Nobita was all alone at home. As there was no light, it was dark and the sun was setting and many uncertain noises were around him. Nobita got scared as there was no one in the house. Suddenly a blue raccoon came out of this dark and Nobita felt like he would faint. The blue raccoon said, 'Don't get scared of me'. Nobita asked him, 'what is your name?' The blue raccoon said, 'I am Doreamon! I am your friend, I am from 22nd century to help you. I am there to solve your 
problems.' There were tears in Nobita's eye and he hugged Doreamon."

“On 24th December, Nobita's friends \& family had a get-together. Nobita said that we want to meet Santa. But his parents told him that there is no Santa in real life. Nobita \& his friends became sad. In midnight, Doraemon became Santa and gifted all the children some gifts and left a note, 'This gift is for you, using the bamboo-copter, come up in the clouds.' When kids got up in the clouds they saw that Doraemon is having a Christmas Party. All children enjoyed the party and thanked Doraemon."
Girls were not liking Ben10 sequences where fighting scenes were shown. Boys were not interested to watch what 'chutki' or 'Barbie' are doing. However, both girls and boys are seen appreciating moral values depicted through these characters. This is also apparent from the stories they have created using their imagination. A focus group, having both boys and girls created a story from a visual shown to them-

"One day Nobita wanted to watch a movie with his parents. But his dad came late and they could go out for movie. They decided to watch the movie on television at home. Then they had dinner together. Nobita realised that his family was very lovely."

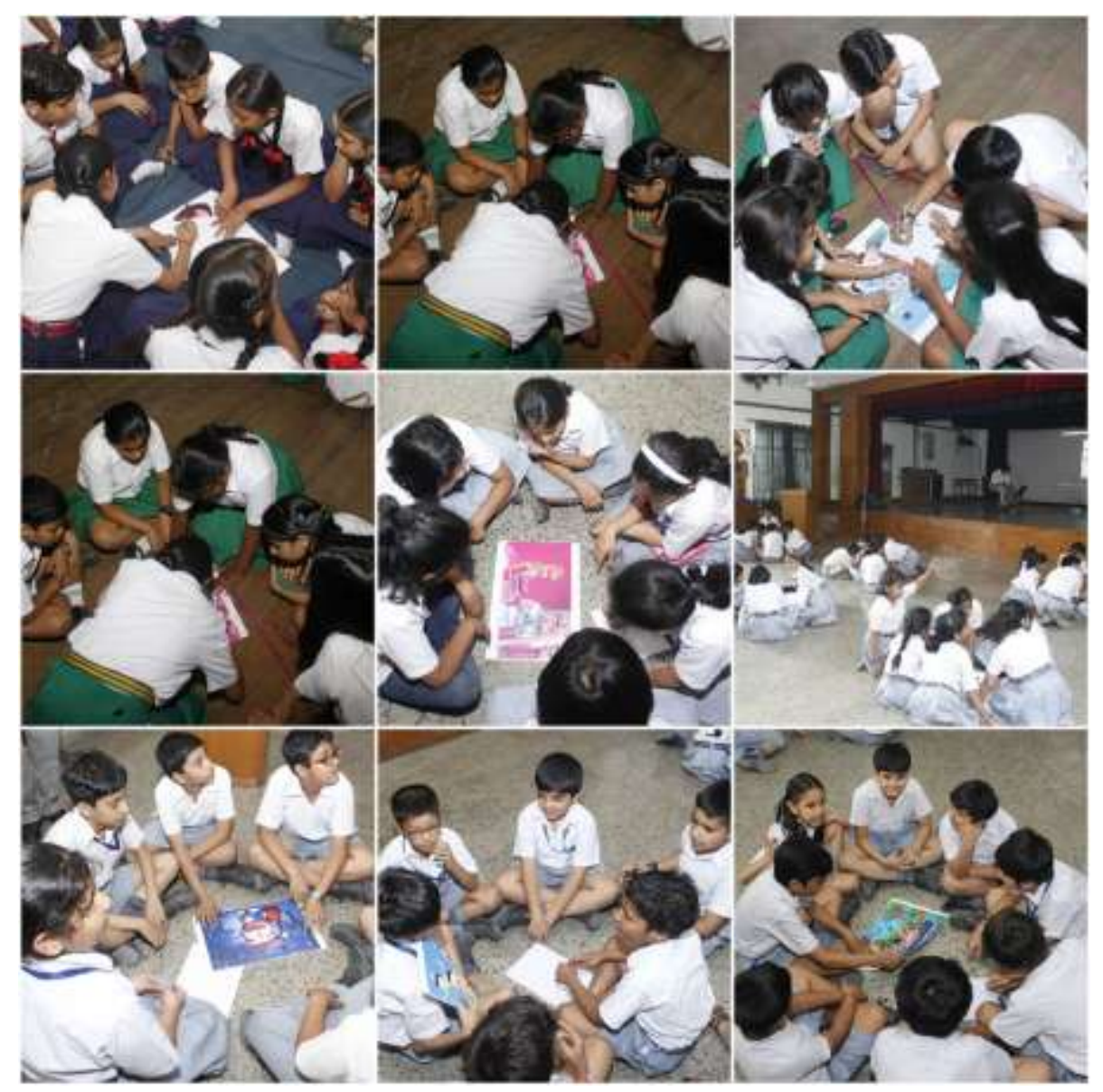

Figure No. 5: Learning by Doing Activity

\section{Behavioural Influence}

They have developed their respective associations with characters, gadgets, colours, settings, dialogues, music, costumes and so on. The likings and choices of boys are remarkably different from that of girls. Doraemon, Ben 10 are largely liked by boys, while girls are devotedly watching Barbie, Chota Bheem etc.
Thus, cartoon programs could act as a home school, to teach a kid the life experience that is not gained from parents or from school due to facilities that is lacked in the normal academic way or in parents' orders. (Habib \& Soliman 2015).

Children are also taught about various lifestyles depicted in cartoon programs. The 
selection of a setting (urban? Rural? Affluent? Poor?), attitudes and behaviours that are portrayed. Shows like Motu Patlu, Chota Bheem, and The Jungle Book have references to occupations of farmer, carpenter, cobbler, cook etc. Doraemon, Ben10, Pokémon etc. have references of scientists, professor, actor, police, doctor, computer professional etc. Children because of their fascinations to certain characters decide what they want to become in future. Children also dream of having a house like Barbie and gadgets like Doreamon and Ben10. They know the difference between a rural and an urban set up. They were clear about what it means to be an affluent and poor. A girl respondent from FGD 13, workshop 2 said, 'I have seen a village and it's exactly how I saw in The Jungle Book and Chota Bheem.' Another boy from FGD 15, workshop 3 said, 'I have never seen a 'well' in the city, it's only in cartoon shows, I don't think so they even exist today'.

Excessive cartoon consumption also leads to the behavioural influences like having mood swings, be demanding with parents, competing with peers etc. When asked about what they want from their favourite cartoon program, children responded differently-

'I really want to have my own space, where I can jump freely and eat anything.'

'I want to have friends like Nobita and Doraemon, who can help me with my homework and can also play with.'

'I want to cook myself in the kitchen.'

'I want to use my mobile phone anytime I want to.'

'My friends tease me that I am fat, I want Ben10 to help me fighting with them.'

'I asked my father to get me a Ben10 watch, a bag and a pencil box, after my class $\mathrm{V}$ result'.

\section{Conclusion}

The impact of cartoon viewing is powerful, to the extent that these children want to meet the characters so that they can interact. Therefore, having built this knowledge base, it is important that parents and teachers must be cautious in exposing their children to only the

Table No. 3: Semiotic analysis of the A/V Clips shown to children: Denotation \& Connotation

\begin{tabular}{|c|c|c|c|}
\hline S.No. & A/V Clip & $\begin{array}{l}\text { Verbal/ Visual Denotation of the } \\
\text { AV/ clip }\end{array}$ & $\begin{array}{c}\text { Verbal/ Visual Connotations by } \\
\text { Children }\end{array}$ \\
\hline 1. & $\begin{array}{l}\text { Chota } \\
\text { Bheem } \\
\text { (POGO) }\end{array}$ & $\begin{array}{l}\text { In this episode, Chota Bheem is seen } \\
\text { fighting with Daku Mangal Singh } \\
\text { and save villagers from all atrocities. }\end{array}$ & $\begin{array}{l}\text { - Bheem is a friendly character who } \\
\text { help the people in need. } \\
\text { Bheem protects his friends and } \\
\text { villagers } \\
\text { - We should help each other and } \\
\text { protect our friends from } \\
\text { difficulties. }\end{array}$ \\
\hline 2. & $\begin{array}{l}\text { Doraemon } \\
\text { (Disney) }\end{array}$ & $\begin{array}{l}\text { In this episode, Doraemon teaches } \\
\text { Nobita a lesson. Nobita is told to not } \\
\text { find shortcuts in life and he must } \\
\text { work hard and do his homework } \\
\text { every day. }\end{array}$ & $\begin{array}{l}\text { - We should obey our parents } \\
\text { - We should not be greedy } \\
\text { - We should not find shortcuts to } \\
\text { our work }\end{array}$ \\
\hline 3. & $\begin{array}{l}\text { Pokemon } \\
\text { (Hungama } \\
\text { TV) }\end{array}$ & $\begin{array}{l}\text { In this episode, Ash, Pikachu \& May } \\
\text { help Prof. Aiden to prevent his } \\
\text { jewels and precious stones from } \\
\text { Team Rocket. Team Rocket tries to } \\
\text { attack them but fail in their attempt. }\end{array}$ & $\begin{array}{l}\text { - Ash, Pikachu \& May are helpful } \\
\text { and friendly. } \\
\text { - We should fight for all challenges } \\
\text { in life }\end{array}$ \\
\hline 4. & $\begin{array}{l}\text { Shin Chan } \\
\text { (Hungama } \\
\text { TV) }\end{array}$ & $\begin{array}{l}\text { Shin Chan and Himawari (his sister) } \\
\text { are playing. Shin Chan lies to his } \\
\text { mother that aliens took away } \\
\text { Himawari. Mother got really scared } \\
\text { and later found that Himawari was } \\
\text { hiding upstairs in the house. She } \\
\text { scol/ded Shin Chan and told him to } \\
\text { not repeat such thing again. }\end{array}$ & $\begin{array}{l}\text { - We should not trouble our mother } \\
\text { like Shin Chan and Himawari } \\
\text { - We should respect our elders } \\
\text { - We must behave courteously with } \\
\text { elders } \\
\text { - We should not lie }\end{array}$ \\
\hline
\end{tabular}


non-destructive and only the morally right content. Their change in emotions, behaviour, perception and attitude under the influence of these programmes must be closely monitored and rectified whenever and however required. Parents being the first teachers of children, must assume liability prioritize and appropriately regulate them and to train them to watch quality programmes.

Cognitive development is essential. Children's cognitive skills can be improved, if they are guided to watch the right content. Children should also be taught to identify the 'good' and 'bad' content under teacher's or parent's supervision. Cartoon programs thus will be an appropriate media literacy tool to learn from the content which they like the most. A cartoon program can teach a child how to control his temper, obey his parents, speak in a polite way, help the poor, aid the old, and lend hand to the young and to work in group without feeling jealous from others. Therefore, the content matters. Schmidt and Vandewater (2008) points out that high-quality educational television programs seem to have positive effects for children's learning, academic skills, and academic engagement.

Bandura describes social cognitive theory as the reciprocal action between environment, behaviour, and cognition, so does media psychology evaluate the interactive process of the system. Cognitive development among children involves the progressive building of learning skills, such as attention, retention and processing of information. These crucial skills enable children to process the sensory information they experience and eventually learn to evaluate, analyse, remember, make comparisons and understand cause and effect.

Media literacy workshops indicated that all elements depicted in every story of the cartoon show, such as history, contemporary happenings, knowledge and moral lessons, grab the child's focus and his assimilation with incredulous ease, to possibly make a profound long-term impact on the child's personalityemotionally and behaviourally.

Apart from moral values, these cartoon shows have plenty to offer. They touch upon every possible subject that could interest children. These include environmental issues, parental care, history, archeology, geology, genetics, moral science, biology, etc. Since these vital subjects are showcased, coated with comic humour and loud fun, cartoons become the best teachers and instructors for children (Rajashree S Adhikary 2015).

Therefore, media literacy to understand cartoon programs in children is very important for their cognitive, emotional and behavioural development. The media literacy workshops organised in schools suggests that such activities can be integrated in school curriculum which might helpful for children in understanding the visual content.

\section{References}

Allison, A. (2002). The cultural politics of

Pokemon capitalism. Media in Transition: Globalization and Convergence, 178-200.

Aggarwal, J.C. (2005). Child Development and Processing of Learning. Delhi: Shipra Publications.

Brotherson, S. (2015) Understanding brain development in young children. Family Science Specialist, NDSU Extension Service.

Bandura, A., Ross, D. and Ross, S.A. (1963). Vicarious reinforcement and imitative learning. Journal of Abnormal and Social Psychology, 67, 601-607. Retrieved from http://dx.doi.org/10.1037/h0045550

Bryant, Jennings, Oliver. (2009). Media Effects: Advances in Theory and Research. Routledge.

Centre for Media Literacy. (2009). Centre for Media Literacy. Retrieved from http://www.medialit.org

Craig A. Anderson, et al. (December 2003). The influence of violent media on youth, psychological science in the public interest. vol. 4, pps. 81-110.

Trend, D. (2007). The myth of media violence: a critical introduction. Oxford, UK: Blackwell Publishing.

Davidson, Emily S., Amy Yasuna, and Alan Tower. (1979). The effects of television cartoons on sex-role stereotyping in young girls. Child Development, Vol. 50, No. 2: 597-600.

Friedrich, Lynette Kohn, Aletha Huston Stein. (1973). Aggressive and prosocial television programs and the natural behavior of preschool children. Monographs of the Society for Research in Child Development, Vol. 38, Issue 4: 1-64. 
Gerbner, G. \& Gross, L. (1976). Living with television: the violence profile. Journal of Communication, 26(2), 172-199.

Gerbner, G., Gross, L., Morgan, M., Signorielli, N., \& Jackson-Beeck, M. (1979). The demonstration of power: violence profile. Journal of Communication, 29(10), 177-196.

KPMG India- FICCI. (2017). Media for the Masses: the promise unfolds (FICCI-KPMG Media and Entertainment Industry Report 2017) \

Habib, K. and Soliman, T. (2015) Cartoons' effect in changing children mental response and behavior. Open Journal of Social Sciences, 3, 248-264. Retrieved from http://dx.doi.org/10.4236/jss.2015.39033

Hobbs, Renee, and Jensen. (2009). The Past, Present, and Future of Media Literacy Education. Journal of Media Literacy Education 1.1, 1-11. Education Research Complete.

Hurlock, E.B. (1981). Developmental psychology- A Life Span Approach. New Delhi: Tata Mc GrawHill.

Kirkorian, H. L., Wartella, E. A., \& Anderson, D. R. (2008). Media and young childrens' learning. The Future of Children. NCBI Resources

Kirsh, S.J. (2006). Cartoon violence and aggression in youth. Aggression and Violent Behavior, 11, 547-557. Retrieved from http://dx.doi.org/10.1016/j.avb.2005.10.002

Livingstone, Van Couvering, \& Thumim. (2008). Comparison of media literacy and information literacy research traditions. In J. COIRO, M. KNOBEL

Livingstone, S. (2003). The Changing Nature and Uses of Media Literacy.

Livingstone, S. (2007). Internet Literacy: Young People's Negotiation of New Online Opportunities. The John D. and Catherine T.
MacArthur Foundation Series on Digital Media and Learning, 101-122.

Livingstone, S., \& Haddon, L. (2009). Young people in the European digital media landscape : a statistical overview with an introduction. Göteborg: NORDICOM.

Marfo, Stephen (2010). The effect of cartooning of children. A Project report. Department of Graphics Schools of Applied Arts, Tarkeradi Polytechnic, Ghana.

Michelsen, Eva Rún. (2009). Animated cartoons, from the old to the new: evolution for the past 100 years. Reykjavik University, Iceland, T-611-NYTI.

OFCOM. (2008). What is media literacy? Publication:

http://www.ofcom.org.uk/advice/media_lite racy/of_med_lit/whatis/ Retrieved on $19^{\text {th }}$ May 2017

UNESCO-Teacher training. (2008). Teacher Training Curricula for Media and Information Literacy. Publication, from UNESCO: http://portal.unesco.org/ci/en/ev.phpURL_I $\mathrm{D}=27064 \&$ URL_DO=DO_TOPIC\&URL_SECTI $\mathrm{ON}=-465 . \mathrm{html}$

Sito, Tom. (2013). Moving innovation: a history of computer animation. Cambridge, Mass: MIT Press.

Thoman, E., Jolls, T., \& Center for Media Literacy. (2008). Literacy for the 21st century: An overview \& orientation guide to media literacy education. Malibu, Calif.: Center for Media Literacy.

Weiss, A., \& Wilson, B. (1996). Emotional Portrayals in Family Television Series That Are Popularamong Children. Journal of Broadcasting \& Electronic Media 40, 1-29

Wilson, B., \& Cantor, J. (1985). Developmental Differences in Empathy with a Television Protagonist'sFear. Journal of Experimental Child Psychology 39(2), 284-99. 